\title{
A COVID-19-fertőzött betegek anesztéziájának és perioperatív ellátásának gyakorlati szempontjai
}

\author{
Végh Tamás dr. - László István dr. - Juhász Marianna dr. \\ Berhés Mariann dr. - Fábián Ákos dr. - Koszta György dr. \\ Molnár Csilla dr. - Fülesdi Béla dr. \\ Debreceni Egyetem, Általános Orvostudományi Kar, Klinikai Központ, \\ Aneszteziológiai és Intenzív Terápiás Klinika, Debrecen
}

\begin{abstract}
A 2019 decemberében kitört koronavírus-fertőzéses világjárványban megbetegedettek ellátása jelentős terhet ró az egészségügyre. Nemcsak azért, mert a betegek egy része intenzív terápiás ellátást igényel, hanem mert a betegség bármely súlyossági formájában szenvedő betegeknek sebészi kezelésre is szükségük lehet. Ennek megoldása pedig jelentős kihívás elé állítja az aneszteziológusokat. Ezen összefoglaló a sebészi kezelést igénylő betegek aneszteziológiai és perioperatív ellátásának gyakorlati aspektusait hivatott bemutatni.
\end{abstract}

Orv Hetil. 2020; 161(17): 692-695

Kulcsszavak: COVID-19-fertőzött beteg, anesztézia, mútét, perioperatív ellátás

\begin{abstract}
Practical aspects of anesthetic and perioperative care for COVID-19 patients
Caring for those affected by the coronavirus outbreak of December 2019 imposed a heavy burden on healthcare systems. Not only because some patients require intensive care, but because patients with any form of the disease may need surgical intervention. Managing these cases is a major challenge for anesthesiologists. The purpose of this summary is to present the practical aspects of anesthetic and perioperative care for patients requiring surgical treatment.
\end{abstract}

Keywords: COVID-19 disease, anesthesia, operation, perioperative care

Végh T, László I, Juhász M, Berhés M., Fábián Á, Koszta Gy, Molnár Cs, Fülesdi B. [Practical aspects of anesthetic and perioperative care for COVID-19 patients]. Orv Hetil. 2020; 161(17): 692-695.

(Beérkezett: 2020. március 27.; elfogadva: 2020. március 30.)

\section{Rövidítések}

COVID-19 = (coronavirus disease 2019) koronavírus-betegség 2019; FFP = (filtering facepiece) részecskeszürő félálarc; HEPA = (high-efficiency particulate air) nagy hatékonyságú részecskeszürő; HME = (heat and moisture exchanger) hő- és nedvességcserélő; RSI = rapid szekvenciális indukció; TCI = (target-controlled infusion) célkontrollált infúzió; UV = ultraibolya

\section{Általános megfontolások}

- Az ellátásban részt vevő team minden tagjának teljes védőfelszerelést kell viselnie:

- FFP2/3 maszk,
- védőszemüveg és pleximaszk,

- vízlepergető ruha,

- szorosan záródó sapka,

- két pár kesztyú.

- A mütőben tartózkodók létszámát a lehető legkisebbre kell csökkenteni.

\section{A mütői munka szervezése}

- A mútő vezetésének arra kell törekednie, hogy csökkentse a mütéti maszkok és védőfelszerelések használatát, valamint minimalizálja a COVID-19 lehetséges expozícióját a viszonylag hosszú (például 12 órás) személyzetváltások ütemezésével. Amennyiben lehetsé- 
ges, a mütéti típusoktól függően célszerű a mütéteket egymás után, egy mútőben elvégezni, és nem egyszerre inditani több mütöt.

- A COVID-19-betegeket az erre előzetesen kijelölt mútőben kell operálni, az anesztéziát külön arra kijelölt munkaállomáson javasolt elvégezni.

- Az ismeretlen COVID-19 statusú beteget a pandémiás időszakban célszerü COVID-19-fertőzöttként kezelni, és a személyzet, valamint az ellátóhely védelme érdekében ugyanolyan óvintézkedések mellett végezzük az anesztéziát és a sebészi beavatkozást [1-3].

\section{A beteg mütőbe történő szállítása}

- Az előkészítő helyiségnek jól szellőzőnek, negatív nyomásúnak kell lennie, melyben legalább 12/óra légcserélődéses ciklus vagy legalább 160 liter/másodperc/beteg természetes szellőzés biztosítható.

- A transzport során a betegnek arcmaszkot kell viselnie.

- A személyzetnek a helyi protokollnak megfelelő védo"felszerelést kell viselnie.

- Amennyiben a beteget intenzív osztályról szállítják a mütőbe, külön erre a célra kijelölt transzport-lélegeztetőgép használata javasolt.

\section{Az aeroszolképződés minimalizálása}

- A beteg előkészítését, az anesztézia bevezetését, az intubációt, az intravascularis és az egyéb kanülök, szondák bevezetését lehetőség szerint negatív nyomású előkészítő helyiségben kell elvégezni.

- A légútbiztosítást lehetőség szerint a leggyakorlottabb aneszteziológusnak kell végeznie.

- Az anesztézia bevezetése során magas hatásfokú hidrofób filtert (HEPA) kell az arcmaszk és a légzőkör vagy ballon közé helyezni.

- Preoxigenizáció során 100\% oxigén adása szükséges, valamint rapid szekvenciális indukció (RSI) ajánlott manuális lélegeztetés nélkül a vírus aeroszol általi ürítésének csökkentésére.

- A preoxigenizáció során a beteg száját és orrát többrétegű nedves gézlappal fedhetjük, vigyázni kell azonban arra, hogy ez a légutakat ne zárja el.

- RSI-hez 1,2 mg/ttkg rokuronium használata javasolt.

- Az RSI módosítható azokban az esetekben, ha az alveolaris-artériás oxigéngradiens magas, a beteg nem tolerál 30 másodpercnyi apnoét, illetve szukcinilkolin adása szükséges. Amennyiben manuális lélegeztetésre van szükség, kis légzési térfogatok alkalmazása javasolt.

- Az éber bronchofiberoszkópos intubáció kerülendő. Alkalmazása csak speciális esetekben ajánlott, mivel a köhögés a vírus ürítését segíti.

- Videolaringoszkóp használata javasolt minden esetben, mivel így a távolság a beteg és az intubáló aneszteziológus között megnő.

- Endotrachealis intubáció javasolt a laringealis maszkok használatával szemben.

\section{Speciális aneszteziológiai megfontolások}

- Az aeroszolképződés és a vírusürítés elkerülése érdekében totális intravénás anesztézia, illetve célkontrollált infúzió (TCI) alkalmazása javasolt folyamatos alvásmélység és neuromuscularis monitorozás mellett.

- Az intraoperatív monitorozás szabályai nem térnek el az általánosan alkalmazott monitorozási szabályoktól. Kritikus állapotú betegeknél azonban, ha a beteg az intenzív osztályról érkezik, a kiterjesztett monitorozást folytatni kell.

- Az altatógépek ki- és bemeneti szárain is magas hatásfokú filterek (HEPA) használata szükséges. A kilégzőszáron extra HEPA/HME filter alkalmazása szükséges.

- Kerüljük a felesleges dekonnektálást az altatógépről.

- Zárt rendszerú szívó alkalmazása javasolt.

- Dekonnekció esetén, illetve transzport-lélegeztetőgépre való áthelyezéskor a tubus lefogása javasolt.

- Az endotrachealis tubus mandzsettájának nyomását folyamatosan szükséges monitorozni az esetleges szivárgás kizárására. Rutinszerűen használt garattampon alkalmazásáról nincsenek adatok.

- A beteg elókészítését, a narkózis bevezetését, az intubációt negatív nyomású előkészítő helyiségben kell elvégezni. Az esetlegesen pozitív nyomású mütőben kerülni kell az aeroszolképződést.

- Minden beavatkozás előtt külön tálcára kell helyezni a beavatkozáshoz, narkózishoz szükséges eszközöket, gyógyszereket. A mütőben csak a legszükségesebb eszközök, gyógyszerek legyenek bent. Minden mást az elökészítő helyiségben kell hagyni.

- Amennyiben egyéb gyógyszerekre, eszközökre van szükség a kézhigiénés szabályok betartásával, cserélt, tiszta kesztyúvel menjen ki az aneszteziológus vagy az asszisztens az előkészítő helyiségbe.

- Az intraoperatív lélegeztetés szabályai nem térnek el az intenzív osztályon alkalmazott gépi lélegeztetés szabályaitól.

- Mellkassebészeti beavatkozás során egylumenú endotrachealis tubus és bronchusblokker használata javasolt. A bronchusblokker pozíciójának ellenőrzéséhez és a légúti váladék/vér stb. eltávolításához, az intraoperatív diagnosztikához egyszer használatos fiberoszkóp használata javasolt.

- Mútét alatt a bronchusblokker lumene zárva tartandó.

- Amennyiben kétlumenú endotrachealis tubus használatára kényszerülünk, egytüdős lélegeztetés során a nem lélegeztetett tüdőt ellátó tubusszár nyitott végére HEPA-filtert kell helyezni.

- COVID-19 fertőzött beteg mellkassebészeti beavatkozása után, illetve minden olyan esetben amikor mellkasi szívódrenázsra van szükség (például légmell kezelése az intenzív osztályon) teljesen zárt rendszerü, digitális elektronikus szívórendszer (THOPAZ) alkalmazása javasolt. A hagyományos, vízzáras mellkasi szí- 
vórendszerek nyílt rendszerek, így a környezet kontaminációját okozhatják.

- Amennyiben mútét során laboratóriumi vizsgálatra/ vérgázvizsgálatra van szükség, a mintát 3 réteg zacskóba kell zárni. A mintát nem javasolt vákuumrendszerú csőpostán továbbítani.

- Az extubációt célszerú úgy végezni, hogy a légutakat zárt rendszerú szívóval kitisztítjuk, majd a tubust dekonnekció nélkül húzzuk ki. Ezzel elkerülhető a nyitott légút miatti aeroszolképződés. Hasznos lehet dexmedetomidin alkalmazása a köhögés csökkentésére. A mély narkózisban történő extubáció nem ajánlott, mert akkor maszkos-ballonos lélegeztetés szükséges - ez pedig növeli az aeroszolképződés veszélyét.

- Az extubációt követően az asszisztens azonnal oxigén arcmaszkot helyez a betegre az aeroszolképződés megakadályozása céljából.

- Amennyiben a beteg légzése kielégítő, és az oxigenizációhoz orrszonda alkalmazása elegendő, a betegre az orrszonda fölé sebészi maszk helyezése szükséges [2-7].

- COVID-19-fertőzött anya esetén császármetszés során a spinális anesztézia az első választandó módszer. Ebben az esetben az anyára az orrszonda fölé sebészi maszkot kell helyezni. A spinális anesztézia elégtelensége vagy komplikációk esetén általános anesztézia bevezetése szükséges a fent említett kautélák betartása mellett [8].

\section{Posztoperatív elhelyezés}

- A COVID-19-fertőzött beteget a többi posztoperatív betegtől elkülönítve kell elhelyezni.

\section{A mútői környezet tisztítása, fertőtlenítése}

- A vírus elsősorban - de nem kizárólagosan - szennyezett környezeti felületekkel való érintkezéssel és aeroszolizálódással terjed. A COVID-19 akár 3 napig képes életben maradni a mútőben gyakran előforduló különféle anyagokon, mint például rozsdamentes acél és müanyag.

- Amennyiben lehetőség van rá, érdemes az altatógépet nagy méretű, átlátszó, egyszer használatos műanyag zsákkal befedni.

- Bizonyítékok vannak arra vonatkozóan, hogy az ultraibolya sugárzás hatásosan csökkenti a bakteriális és virális kontaminációt.

- Önmagában azonban az UV-fény nem elégséges a mütők, egészségügyi helyiségek fertőtlenítésére, hiszen vannak árnyékolt területek is, ahová az UV-fény nem jut el. Ezért UV-lámpa alkalmazása mellett szükség van alapos fertőtlenítő takarításra is.

- Célszerü alkoholalapú kézfertőtlenítő oldatot elhelyezni az aneszteziológus bal oldalán, a jobb oldalán pedig egy cipzárral zárható múanyag zacskóval bélelt szemetest, és az összes szennyezett múszert (például laringoszkópnyél és -lapoc, vezetőnyárs) a zsákba kell helyezni, majd biztonságosan le kell zárni.

- Javasolt a mütóben és az aneszteziológus környezetében tiszta és piszkos területek kijelölése.

- Az anesztézia bevezetését követően javasolt, hogy kvaterner ammóniumvegyületet és alkoholt tartalmazó fertőtlenítő törlőkendővel töröljék le az összes berendezést és felületet egy felülről lefelé történő tisztítási eljárással, amely megfelelő a biológiai terhelés csökkentéséhez.

- Különös tekintettel kell lenni az intravascularis eszközökre. Célszerü zárt rendszereket alkalmazni.

- Injekció beadása előtt a csatlakozókat, hármascsapokat alaposan fertötleníteni kell.

- Minden eset után cserélni kell a légzőkört, a HEPA- és HME-filtereket, a 'soda lime'-ot.

- Törekedni kell egyszer használatos eszközök használatára.

- A beteggel érintkező minden textíliát, melegítő takarót stb. a beavatkozás végén az erre rendszeresített hulladékgyưjitőben kell tárolni, és cserélni kell őket.

- A beavatkozást követően a mütő és az előkészítő helyiség fertőtlenítése szükséges.

- Amennyiben lehetséges, az intraoperatív adatok rögzítése (aneszteziológiai jegyzókönyv) elektronikus úton történjen. Ha ez nem lehetséges, az aneszteziológiai jegyzőkönyvet is fertőtleníteni kell. Lehetőség szerint kerüljük a felesleges dokumentáció mütőbe kerülését, illetve gondoskodjunk annak fertőtlenítéséről [9].

Anyagi támogatás: A szerzők anyagi támogatásban nem részesültek.

Szerzői munkamegosztás: V. T.: A kézirat elkészítése. F. B., V. T., F. Á., B. M., L. I., M. Cs., K. Gy.: A kézirat szerkesztése. J. M., F. B.: A közlemény bírálata. A cikk végleges változatát valamennyi szerző elolvasta és jóváhagyta.

Érdekeltségek: A szerzőknek nincsenek érdekeltségeik.

\section{Irodalom}

[1] Kim HJ, Ko JS, Kim TY; Scientific Committee on Korean Society of Anesthesiologists. Recommendations for anesthesia in patients suspected of coronavirus 2019-nCoV infection. Korean J Anesthesiol. 2020 Mar 16. Doi: 10.4097/kja.20110. [Epub ahead of print]

[2] Peng PWH, Ho PL, Hota SS. Outbreak of a new coronavirus: what anesthetists should now. Br J Anesth. 2020 Feb 27. Doi: 10.1016/j.bja.2020.02.008. [Epub ahead of print]

[3] Wax RS, Christian MD. Practical recommendations for critical care and anesthesiology teams caring for novel coronavirus (2019-nCoV) patients. Can J Anesth. 2020 Feb 12. Doi: 10.1007/s12630-020-01591-x. [Epub ahead of print]

[4] Ti LK, Ang LS, Foong TW, et al. What we do when a COVID-19 patient needs an operation: operating room preparation and guidance. Can J Anesth. 2020 Mar 6. Doi: 10.1007/s12630020-01617-4. [Epub ahead of print] 
[5] Dexter F, Parra MC, Brown JR, et al. Perioperative COVID-19 defense: an evidence-based approach for optimization of infection control and operating room management. Anesth Analg. 2020 Mar 24. Doi: 10.1213/ANE.0000000000004829. [Epub ahead of print]

[6] Chen X, Liu Y, Gong Y, et al.; Chinese Society of Anesthesiology, Chinese Association of Anesthesiologists. Perioperative management of patients infected with the novel coronavirus: recommendation from the Joint Task Force of the Chinese Society of Anesthesiology and the Chinese Association of Anesthesiologists. Anesthesiology 2020 Mar 19. Doi: 10.1097/ ALN.0000000000003301. [Epub ahead of print]

[7] Zhao S, Ling K, Yan H, et al. Anesthetic management of patients with suspected or confirmed 2019 novel coronavirus infection during emergency procedures. J Cardiothorac Vasc Anesth.
2020 Feb 28. Doi: 10.1053/j.jvca.2020.02.039. [Epub ahead of print]

[8] Chen R, Zhang Y, Huang L, et al. Safety and efficacy of different anesthetic regimens for parturients with COVID-19 undergoing Cesarean delivery: a case series of 17 patients. J Can Anesth. 2020 Mar 16. Doi: 10.1007/s12630-020-01630-7. [Epub ahead of print]

[9] Greenland JR, Michelow MD, Wang L, et al. COVID-19 infection: implications for perioperative and critical care physicians. Anesthesiology 2020 Mar 19. Doi: 10.1097/ ALN.0000000000003303. [Epub ahead of print]

(Végh Tamás dr., Debrecen, Nagyerdei krt. 98., 4032 e-mail: veghdr@gmail.com)

A cikk a Creative Commons Attribution 4.0 International License (https://creativecommons.org/licenses/by/4.0/) feltételei szerint publikált Open Access közlemény, melynek szellemében a cikk bármilyen médiumban szabadon felhasználható, megosztható és újraközölhetö, feltéve, hogy az eredeti szerző és a közlés helye, illetve a CC License linkje és az esetlegesen végrehajtott módosítások feltüntetésre kerülnek. (SID_1) 